\title{
Nodular goiter with amyloid deposition in an elderly patient: fine-needle cytology diagnosis and review of the literature
}

\author{
Vincenzo Di Crescenzo ${ }^{1}$, Alfredo Garzi ${ }^{1}$, Fara Petruzziello², Mariapia Cinelli ${ }^{3}$, Lucio Catalano ${ }^{4}$, Pio Zeppa ${ }^{1}$, \\ Mario Vitale $1^{*}$
}

From 26th National Congress of the Italian Society of Geriatric Surgery

Naples, Italy. 19-22 June 2013

\begin{abstract}
Background: Amyloidosis is a systemic disease characterized by the extracellular deposition of amyloid fibrils in different organs and tissues. The thyroid gland may be affected by diffuse or nodular amyloid deposits, along with multiple myeloma (MM) (Amyloid Light-Chain Amyloidosis, AL amyloidosis) or chronic inflammatory diseases (Amyloid A Amyloidosis, AA amyloidosis), but thyroid gland involvement rarely appears as the first clinical manifestation in both conditions. The present study reports a case of primary thyroidal nodular amyloid goiter diagnosed by fine-needle cytology (FNC) in an elderly patient.

Case report: A 66-year-old female patient presented with dysphagia and hoarseness; the patient suffered from rheumatoid arthritis but did not have kidney failure or altered thyroid function. Ultrasound examination (US) showed a $30 \mathrm{~mm}$ irregular, hypoechoic area in the left thyroid lobe. FNC showed abundant, dense and amorphous material similar to the one stained in purple at Diff-Quik stain and pinkish at the Papanicolaou. Spindle cells with thin, bland and bent nuclei were scattered in this material; few thyroid follicular cells were also present. An alcohol-fixed smear was stained with Congo red: the amyloid material appeared cherry red and it also showed apple-green birefringence when observed with a polarizing microscope. A differential diagnosis between different thyroid pathologies was considered and the cytological diagnosis of nodular amyloid goiter was pointed out. The patient underwent thyroid lobectomy and the subsequent histological examination confirmed the cytological diagnosis.

Conclusions: FNC is a safe and effective procedure for the diagnosis of thyroid amyloidosis. Congo red-stained smears can be used to demonstrate the presence of amyloid material, showing the typical green birefringence under polarized light. An early and accurate cytological diagnosis may suggest an hematological screening and the appropriate treatment for the thyroid nodule.
\end{abstract}

\section{Background}

Senescence and aging involving several mechanisms like oxidative stress and elevated ROS (Reactive oxygen species). They has been implicated in cancer, diabetes, neurodegenerative, cardiovascular and other diseases [1,2]. Several stressors, including high-caloric diets, physical activity, chemicals, drugs and pollutants, induce oxidants

\footnotetext{
* Correspondence: mavitale@unisa.it

'Medicine and Surgery, University of Salerno, Baronissi, Salerno, Italy

Full list of author information is available at the end of the article
}

overproduction [3]. Amyloidosis includes different forms characterized by the extracellular accumulation of insoluble, antiparallel $\beta$-pleated sheets of fibrils of proteins in different tissues and organs [4]. Amyloidosis is traditionally classified as Primary Amyloidosis (PA), arising from plasma cells diseases such as multiple myeloma (MM) [5] or other immunocyte dyscrasias, and Secondary Amyloidosis (SA) caused by a variety of degenerative, metabolic and inflammatory diseases [6-12]. Amyloidosis may involve different organs with different

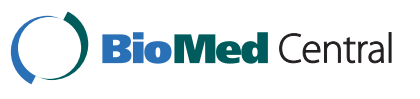

(c) 2013 Di Crescenzo et al.; licensee BioMed Central Ltd. This is an open access article distributed under the terms of the Creative Commons Attribution License (http://creativecommons.org/licenses/by/2.0), which permits unrestricted use, distribution, and reproduction in any medium, provided the original work is properly cited. 
clinical manifestations related to the corresponding functions. Different types of human proteins have been identified as possible causative agents of amyloidosis [13], including amyloid light chain, SAA, $\beta$ amyloid/APP and transthyretin [14]. Despite the different etiologies, organs involved, clinical manifestations and variety of proteins that can cause amyloidosis, a common feature is the accumulation of insoluble proteins arranged in cross- $\beta$-pleated sheet structures regardless of their source, primary structure or function [8]. Amyloid goiter (AG) is a rare condition characterized by thyroid infiltration of amyloid material, which causes thyroid gland enlargement and atrophy of thyroid follicles [15-18]. The most commonly reported clinical features of these patients are rapid, painless thyroid gland enlargement that may be associated with dysphagia, dyspnea, or hoarseness $[15,16]$. AG has been infrequently described $[16,18]$ and most of the reported cases mainly refers to patients suffering from systemic amyloid A (AA) amyloidosis or long-standing predisposing diseases $[19,20]$. Palpable neck masses are not a rare occurrence, some time representing a challenging diagnostic dilemma with unusual extrathyroidal masses [21,22]. Fine-needle cytology (FNC) is a primary diagnostic tool in preoperative diagnosis of thyroid nodules [23-28]. Cellular biomarkers, such as endothelial progenitor cells, whose frequency increase in peripheral blood of cancer patients and decrease in those suffering from cardiovascular diseases [29-31], are unfortunately lacking. However, the application of immunocytochemistry (ICC), flow cytometry (FC) and molecular techniques to FNC has dramatically increased the sensitivity of the method [28,32-38]. The identification of chromosomal aberrations or differences in the expression profiles of suitable membrane ion channels, such as ion channels, whose expression may be up-regulated under pathological conditions [39-43], might favour amyloidosis recognition. These advantages are enhanced in case of AG, which does not require surgical treatment, and even more in elderly patients, for whom surgery is generally more burdensome, complex and expensive than younger patients [44-46]. A case of nodular AG diagnosed by FNC is here described; differential diagnosis and clinical implication of the FNC diagnosis are described accordingly.

\section{Case report}

A 66-year-old female with a palpable thyroid nodule, complaining of dysphagia and hoarseness, was admitted to the outpatient endocrinology clinics of the Azienda Ospedaliera Universitaria, University of Salerno. The patient suffered from a light form of rheumatoid arthritis and did not have kidney failure. She also complained of painless thyroid gland enlargement in the previous 5 months. Serum levels of thyroid hormones and TSH were in the normal range, including calcitonin. Ultrasound examination showed a $30 \mathrm{~mm}$ large, irregular in shape, hypoechoic area in the left thyroid lobe. The remaining gland was normal in size and shape. No relevant lymph nodes were detected. The patient underwent US-guided FNC with rapid on-site evaluation (ROSE), as previously described $[47,48]$. The diagnostic procedure and its related risks were first discussed with the patient, who was informed that 1 or 2 additional passes might have been needed, and an informed consent was obtained. The first smear was immediately Diff-Quik stained and evaluated on site. Two additional passes were used to prepare four alcohol-fixed smears that were subsequently used for Papanicoaou, Congo red stain and immunocytochemistry using thyroglobulin antibody. Technical details for both procedures have been previously described $[32,49,50]$.

\section{Results}

The smears were moderately cellular with the presence of abundant amorphous material interspersed among few follicular cells (Figure 1). This material was more solid and hyaline than the colloid and appeared darkviolet blue on the Diff-Quik and pinkish-orange on the Papanicolaou-stained smears respectively. Numerous spindle cells were interspersed in this amorphous material. These cells were mainly isolated and showed small spindle and bent nuclei with dense compact chromatin without nucleoli and showed lack of cytoplasm. The few follicular cells were present in small groups at the edges of this material and showed occasional cytoplasmic vacuolation with paravacuolar granulations. Because of these cytological features, one of the alcohol-fixed smear was stained with Congo red using an appropriate positive control. The smear showed an amorphous material which appeared dense, orange and brilliant and showed a metachromatic green under the polarized microscope (Figure 2). Follicular cells showed cytoplasmic positivity at the immunostain for thyroglobulin, performed on the additional smear assessing the thyroid origin.

\section{Discussion}

Amyloidosis refers to a variety of conditions in which insoluble proteins are deposited in the extracellular space of various organs or tissues. Approximately 60 different proteins have been identified, giving the name to the different clinical forms prefixed with the letter A $[9,14]$. Therefore, amyloidosis is termed AL amyloidosis in case of overproduction of immunoglobulin light chains in MM, and AA amyloidosis in case of continuous acute phase protein production, as in chronic inflammations. AL amyloidosis is caused by tissue-infiltrating proteins from monoclonal immunoglobulin light chains. AL amyloid is made of proteins arranged in 


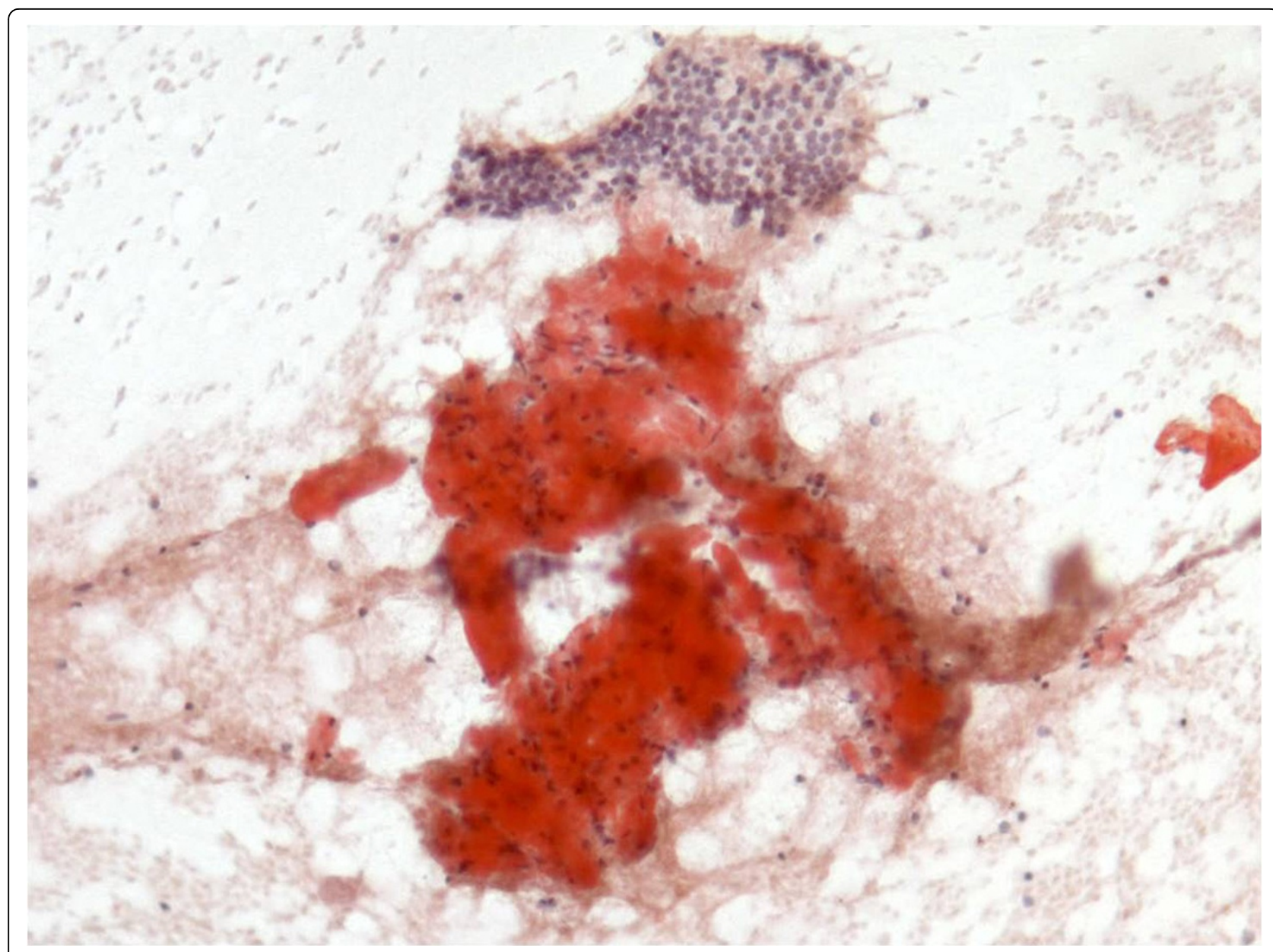

Figure 1 Abundant amorphous amyloid material appearing solid dark-violet blue on the Diff-Quik stain (Diff-Quik stain $103 \mathrm{X}$ ).

cross- $\beta$-pleated sheet structures [4]. Fibrils are usually formed by $\mathrm{N}$-terminal fragments of the variable region of an immunoglobulin light chain, although they may occasionally include part of a constant region or may be formed by whole light chain $[5,6]$. Only a small portion of the light chain is able to form amyloid fibrils: this property is likely correlated with the distinctive structural features of amyloidogenic light chains, as almost $70 \%$ of them are $\lambda$ isotype and the $\mathrm{V} \lambda 6 \mathrm{a}$ and $\mathrm{V} \lambda 3 \mathrm{r}$ genes encode nearly $40 \%$ of these chains [7]. Amyloidosis is classified as 'localized' when it affects one body organ or tissue type and 'systemic' when more than one organ or system are involved; it was also classified as 'primary' when related to disorders of immunocompetent cells such as MM or other plasma cells dyscrasias and 'secondary' or 'reactive' when occurring as a complication of chronic degenerative, inflammatory infective or autoimmune diseases $[4,7,8,12-14]$. Clinical relevance and prognosis of amyloidosis largely depend on the organ involved. In case of AG, the prognosis mostly depends on the primary disease and the possible involvement of other organs [4]. In case of sole thyroid localization, prognosis is reported to be relatively favorable and conservative treatment or limited surgery is recommended. As for FNC diagnosis, because of the rapidly growing mass and the presence of spindle cells in the smears, the differential diagnosis of different thyroid and extra-thyroid benign and malignant entities (i.e. mesenchymal tumors of the neck such as pseudosarcomatous lesions, fibrosarcoma and other mesenchymal malignancies) was pointed out [51-56]. However these lesions were excluded because of the bland appearance of the above spindle cells and because of the amyloid material that was clearly different from the fibrous stroma fragments that may be observed in mesenchymal tumors. Conversely, because of the presence of amyloid material and spindle cells, a possible spindle cell medullary thyroid carcinoma was considered. The bland appearance of the nuclei and the normal serum levels of calcitonin ruled out this possibility. Finally, the optical properties of amyloid material, the presence of few benign follicular cells and the small number of spindle 


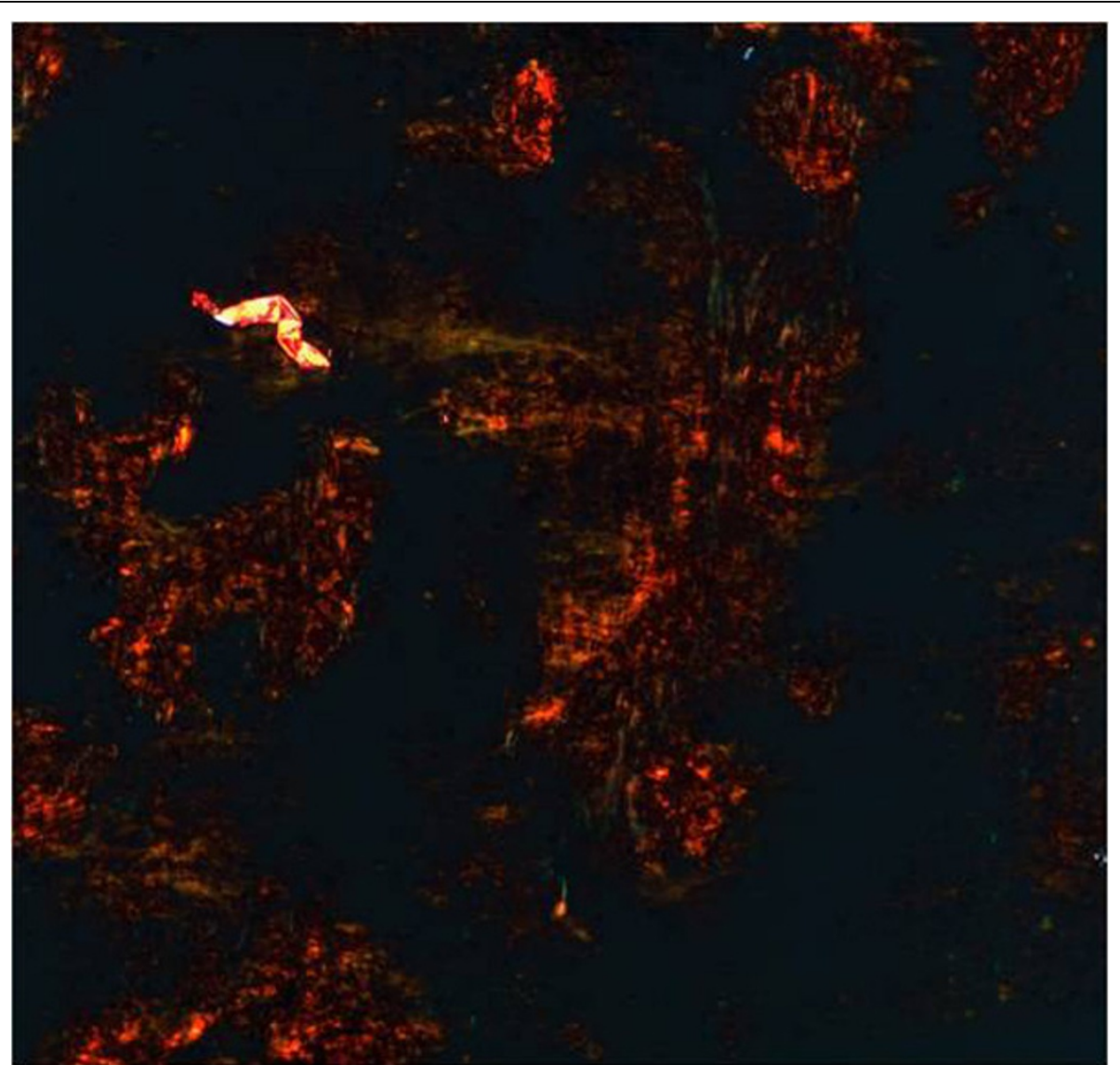

Figure 2 Amyloid deposit, Congo red stained, as it appears under polarized light: red with apple-green birefringence.

cells favored the diagnosis of AG. On the basis of the cytological diagnosis, a conservative surgery was performed and the histological analysis confirmed the FNC diagnosis of AG. In conclusion, although rare, AG may be diagnosed by FNC, provided that the amyloid nature of accumulated material is identified. The cytological diagnosis may be useful for a timely screening for systemic amyloidosis and for an adequate treatment of the thyroid localization avoiding useless extensive surgical treatments.

\section{Conclusions}

FNC is a safe and effective procedure for the diagnosis of thyroid amyloidosis. Congo red-stained smears can be used to demonstrate the presence of amyloid material, showing the typical green birefringence under polarized light. An early and accurate cytological diagnosis may suggest an hematological screening and the appropriate treatment for the thyroid nodule.

\section{Competing interests}

The authors declare that they have no competing interests.

\section{Authors' contributions}

MV: conception and design, interpretation of data, AG, PZ, VDS, AG, LC, MPC acquisition of data, drafting the manuscript, PZ, MV: critical revision, given final approval of the version to be published.

\section{Authors' information}

VDC $=$ Aggregate Professor of Thoracic Surgery at University of Salerno $A G=$ Aggregate Professor of Pediatric Surgery at University of Salerno $\mathrm{FP}=$ Assistant of Hematology at Pausilipon Hospital, Naples

$\mathrm{MC}=$ Aggregate Professor of Anatomy, University of Naples "Federico II" LC= Assistant of Hematology at University of Naples "Federico II" $\mathrm{PZ}=$ Associate Professor of Pathology at University of Salerno $\mathrm{MV}=$ Associate Professor of Endocrinology at University of Salerno

\section{Declarations}

Funding for this article came from University funds.

This article has been published as part of BMC Surgery Volume 13 Supplement 2, 2013: Proceedings from the 26th National Congress of the Italian Society of Geriatric Surgery. The full contents of the supplement are available online at http://www.biomedcentral.com/bmcsurg/supplements/ $13 / 52$

\section{Authors' details}

${ }^{1}$ Medicine and Surgery, University of Salerno, Baronissi, Salerno, Italy. ${ }^{2}$ Pausilipon Hospital, Naples, Italy. ${ }^{3}$ Public Health, University of Naples "Federico II", Naples, Italy. ${ }^{4}$ Hematology, Biochemistry and Biomedical Biotechnology, University of Naples "Federico II", Naples, Italy.

Published: 8 October 2013 


\section{References}

1. Testa D, Guerra G, Marcuccio G, Landolfo PG, Motta G: Oxidative stress in chronic otitis media with effusion. Acta oto-laryngologica 2012, 132(8):834-837.

2. Cattaneo F, laccio A, Guerra G, Montagnani S, Ammendola R: NADPHoxidase-dependent reactive oxygen species mediate EGFR transactivation by FPRL1 in WKYMVm-stimulated human lung cancer cells. Free radical biology \& medicine 2011, 51(6):1126-1136.

3. Conti V, Russomanno G, Corbi G, Guerra G, Grasso C, Filippelli W, Paribello V, Ferrara N, Filippelli A: Aerobic training workload affects human endothelial cells redox homeostasis. Medicine and Science in Sports and Exercise 2013, 45(4):644-653.

4. Gertz MA: The classification and typing of amyloid deposits. Am J Clin Pathol 2004, 121(6):787-789.

5. Petruzziello F, Zeppa P, Ciancia G, Cozzolino I, Fernandez LS, Cervasio M, Musto P, D'Auria F, Vita G, Morabito F, et al: Cytological and histological detection of amyloid deposits in bone marrow of patients affected by multiple myeloma. Leuk Lymphoma 2011, 52(12):2304-2307.

6. Pascale R, Vitale M, Zeppa P, Russo E, Esposito S: [Diabetic foot: definitions]. Infez Med 2012, 20(Suppl 1):5-7.

7. Swan N, Skinner M, O'Hara CJ: Bone marrow core biopsy specimens in AL (primary) amyloidosis. A morphologic and immunohistochemical study of 100 cases. Am J Clin Pathol 2003, 120(4):610-616.

8. Rocken C, Sletten K: Amyloid in surgical pathology. Virchows Arch 2003, 443(1):3-16

9. Westermark P, Benson MD, Buxbaum JN, Cohen AS, Frangione B, Ikeda S, Masters CL, Merlini G, Saraiva MJ, Sipe JD: Amyloid: toward terminology clarification. Report from the Nomenclature Committee of the International Society of Amyloidosis. Amyloid 2005, 12(1):1-4

10. Ferreira ST, Vieira MN, De Felice FG: Soluble protein oligomers as emerging toxins in Alzheimer's and other amyloid diseases. IUBMB Life 2007, 59(4-5):332-345.

11. Chiang PK, Lam MA, Luo Y: The many faces of amyloid beta in Alzheimer's disease. Curr Mol Med 2008, 8(6):580-584.

12. Vitale M, Zeppa P, Esposito I, Esposito S: [Infected lesions of diabetic foot]. Infez Med 2012, 20(Suppl 1):14-19.

13. Kaplan B, Martin BM, Livneh A, Pras M, Gallo GR: Biochemical subtyping of amyloid in formalin-fixed tissue samples confirms and supplements immunohistologic data. Am J Clin Pathol 2004, 121(6):794-800.

14. Sipe JD, Benson MD, Buxbaum JN, Ikeda S, Merlini G, Saraiva MJ, Westermark P: Amyloid fibril protein nomenclature: 2010 recommendations from the nomenclature committee of the International Society of Amyloidosis. Amyloid 2012, 17(3-4):101-104.

15. Ibrahimov M, Yilmaz M, Kilic E, Akil F, Rasidov R, Karaman E: Rapidly progressive thyroid mass: amyloid goiter. J Craniofac Surg 23(6):e555-556.

16. Villa F, Dionigi G, Tanda ML, Rovera F, Boni L: Amyloid goiter. Int J Surg 2008, 6(Suppl 1):S16-18.

17. Ozdemir BH, Uyar P, Ozdemir FN: Diagnosing amyloid goitre with thyroid aspiration biopsy. Cytopathology 2006, 17(5):262-266

18. Law JH, Dean D, Scheithauer B, Earnest F, Sebo TJ, Fatourechi V: Symptomatic Amyloid Goiters: Report of 5 Cases. Thyroid 2013.

19. Turhan lyidir O, Altay M, Konca Degertekin C, Altinova A, Karakoc A Ayvaz G, Arslan M, Onec K, Arinsoy T, Cesur N, et al: Diffuse amyloid deposition in thyroid gland: a cause for concern in familial Mediterranean fever. Amyloid 19(3):161-162

20. Febrero B, Rios A, Rodriguez JM, Ferri B, Polo L, Parrilla P: Giant amyloid goiter in Crohn's disease. Endocr Pathol 2012, 23(4):260-263.

21. Soscia A, Guerra G, Cinelli MP, Testa D, Galli V, Macchi V, De Caro R: Parapharyngeal ectopic thyroid: the possible persistence of the lateral thyroid anlage. Clinical case report. Surg Radiol Anat 2004, 26(4):338-343.

22. Cooper DS, Doherty GM, Haugen BR, Kloos RT, Lee SL, Mandel SJ, Mazzaferri EL, Mclver B, Pacini F, Schlumberger M, et al: Revised American Thyroid Association management guidelines for patients with thyroid nodules and differentiated thyroid cancer. Thyroid 2009, 19(11):1167-1214.

23. Vitale M: Intratumor BRAF(V600E) Heterogeneity and Kinase Inhibitors in the Treatment of Thyroid Cancer: A Call for Participation. Thyroid 2013, 23(4):517-519.

24. Kim Ml, Alexander EK: Diagnostic use of molecular markers in the evaluation of thyroid nodules. Endocr Pract 2012, 18(5):796-802.

25. Marotta V, Guerra A, Zatelli MC, Uberti ED, Di Stasi V, Faggiano A, Colao A Vitale M: BRAF mutation positive papillary thyroid carcinoma is less advanced when Hashimoto's thyroiditis lymphocytic infiltration is present. Clin Endocrinol (Oxf) 2013.

26. Guerra A, Marotta V, Deandrea M, Motta M, Limone PP, Caleo A, Zeppa P, Esposito S, Fulciniti F, Vitale M: BRAF (V600E) associates with cytoplasmatic localization of p27kip1 and higher cytokeratin 19 expression in papillary thyroid carcinoma. Endocrine 2013, 44(1):165-171.

27. Bellevicine C, Cozzolino I, Malapelle U, Zeppa P, Troncone G: Cytological and molecular features of papillary thyroid carcinoma with prominent hobnail features: a case report. Acta Cytol 2012, 56(5):560-564

28. Alexander EK, Kennedy GC, Baloch ZW, Cibas ES, Chudova D, Diggans J, Friedman L, Kloos RT, LiVolsi VA, Mandel SJ, et al: Preoperative diagnosis of benign thyroid nodules with indeterminate cytology. N Engl J Med 2012, 367(8):705-715.

29. Moccia F, Bonetti E, Dragoni S, Fontana J, Lodola F, Berra Romani R, Laforenza U, Rosti V, Tanzi F: Hematopoietic progenitor and stem cells circulate by surfing on intracellular Ca2+ waves: A novel target for cellbased therapy and anti-cancer treatment? Curr Signal Transd T 2012, 7(7):161-176.

30. Moccia F, Dragoni S, Lodola F, Bonetti E, Bottino C, Guerra G, Laforenza U, Rosti $\mathrm{V}$, Tanzi F: Store-dependent $\mathrm{Ca}(2+)$ entry in endothelial progenitor cells as a perspective tool to enhance cell-based therapy and adverse tumour vascularization. Curr Med Chem 2012, 19(34):5802-5818.

31. Moccia F, Lodola F, Dragoni S, Bonetti E, Bottino C, Guerra G, Laforenza U, Rosti V, Tanzi F: Ca2+ Signalling in Endothelial Progenitor Cells: A Novel Means to Improve Cell-Based Therapy and Impair Tumour Vascularisation. Curr Vasc Pharmacol 2012

32. Cozzolino I, Scognamiglio G, Sosa Fernandez LV, Zeppa P: Lymph nodes fine needle cytology in the diagnosis of infectious diseases: cytological and histological correlations. Infez Med 2012, 20(Suppl 3):16-20.

33. Hodak SP, Rosenthal DS: Information for clinicians: commercially available molecular diagnosis testing in the evaluation of thyroid nodule fineneedle aspiration specimens. Thyroid 2013, 23(2):131-134.

34. Guerra A, Di Stasi V, Zeppa P, Faggiano A, Marotta V, Vitale M: BRAFV600E assessment by pyrosequencing in fine needle aspirates of thyroid nodules with concurrent Hashimoto's thyroiditis is a reliable assay. Endocrine 2013.

35. Zeppa P, Sosa Fernandez LV, Cozzolino I, Ronga V, Genesio R, Salatiello M, Picardi M, Malapelle U, Troncone G, Vigliar E: Immunoglobulin heavy-chain fluorescence in situ hybridization-chromogenic in situ hybridization DNA probe split signal in the clonality assessment of lymphoproliferative processes on cytological samples. Cancer Cytopathol 2012, 120(6):390-400

36. Sosa Fernandez LV, Plaitano F, Varone V, Cozzolino I: Lymph node fine needle cytology in the diagnosis of infectious diseases and ancillary techniques. Infez Med 2012, 20(Suppl 3):21-25.

37. Vitale M: SEREX: a promising approach for identification of thyroid cancer serological biomarkers. Clin Endocrinol (Oxf) 2013, 79(1):12-13.

38. Marotta V, Guerra A, Sapio MR, Vitale M: RET/PTC rearrangement in benign and malignant thyroid diseases: a clinical standpoint. Eur J Endocrinol 2011, 165(4):499-507.

39. Donghi R, Longoni A, Pilotti S, Michieli P, Della Porta G, Pierotti MA: Gene p53 mutations are restricted to poorly differentiated and undifferentiated carcinomas of the thyroid gland. J Clin Invest 1993 , 91(4):1753-1760

40. Lodola F, Laforenza U, Bonetti E, Lim D, Dragoni S, Bottino C, Ong HL, Guerra G, Ganini C, Massa M, et al: Store-operated Ca2+ entry is remodelled and controls in vitro angiogenesis in endothelial progenitor cells isolated from tumoral patients. PLoS One 2012, 7(9):e42541.

41. Monteith GR, McAndrew D, Faddy HM, Roberts-Thomson SJ: Calcium and cancer: targeting Ca2+ transport. Nat Rev Cancer 2007, 7(7):519-530.

42. Prevarskaya N, Skryma R, Shuba Y: Calcium in tumour metastasis: new roles for known actors. Nat Rev Cancer 2011, 11(8):609-618.

43. Sanchez-Hernandez Y, Laforenza U, Bonetti E, Fontana J, Dragoni S, Russo M, Avelino-Cruz JE, Schinelli S, Testa D, Guerra G, et al: Storeoperated $\mathrm{Ca}(2+)$ entry is expressed in human endothelial progenitor cells. Stem Cells Dev 2010, 19(12):1967-1981.

44. Passler C, Avanessian R, Kaczirek K, Prager G, Scheuba C, Niederle B: Thyroid surgery in the geriatric patient. Arch Surg 2002, 137(11):1243-1248.

45. Gervasi R, Orlando G, Lerose MA, Amato B, Docimo G, Zeppa P, Puzziello A: Thyroid surgery in geriatric patients: a literature review. BMC Surg 2012 12(Suppl 1):S16. 
46. Repetto L, Venturino A, Fratino L, Serraino D, Troisi G, Gianni W, Pietropaolo M: Geriatric oncology: a clinical approach to the older patient with cancer. Eur J Cancer 2003, 39(7):870-880.

47. Bellevicine C, Malapelle U, laccarino A, Schettino P, Napolitano V, Zeppa P, Troncone G: Foamy gland pancreatic ductal adenocarcinoma diagnosed on EUS-FNA: a histochemical, immunohistochemical, and molecular report. Diagn Cytopathol 2013, 41(1):77-80.

48. D'Antonio A, Baldi C, Memoli D, Caleo A, Rosamilio R, Zeppa P: Fine needle aspiration biopsy of intraparotid spindle cell lipoma: a case report. Diagn Cytopathol 2013, 41(2):171-173.

49. Cipullo C, Amato B, Vigliar E, Di Crescenzo V, Zeppa P: Lymph node fine needle cytology in the diagnosis of infectious diseases and reactive unspecific processes. Infez Med 2012, 20(Suppl 3):30-33.

50. Cozzolino I, Vigliar E, Sosa Fernandez LV, Selleri C, Pepe S, Vitale M, Triggiani M, Zeppa P: Non lymphomatous clonal B-Cell populations in enlarged lymph nodes in acquired immunodeficiency syndrome. Infez Med 2012, 20(Suppl 2):35-42.

51. Cozzolino I, Zeppa R, Zeppa P: Lymph nodal Merkel cell carcinoma: primary tumor or metastasis from unknown primary site? I Cutan Pathol 2012, 38(10):836-837.

52. Stanzione B, Cozzolino I, Arpino G, Vigliar E, Virginia SF, Zeppa P: Multiple metachronus proliferative fasciitis occurring in different anatomic regions: a case report and review of the literature. Pathol Res Pract 2012, 208(2):126-130.

53. D'Antonio A, Paolella G, Zeppa P: Rapidly growing intraparotid mass in a young child. J Craniofac Surg 2012, 23(4):e305-306.

54. Kaushal S, Iyer VK, Mathur SR, Ray R: Fine needle aspiration cytology of medullary carcinoma of the thyroid with a focus on rare variants: a review of 78 cases. Cytopathology 2011, 22(2):95-105.

55. Dey P, Mallik MK, Gupta SK, Vasishta RK: Role of fine needle aspiration cytology in the diagnosis of soft tissue tumours and tumour-like lesions. Cytopathology 2004, 15(1):32-37.

56. Rossi ED, Martini M, Cingolani N, Ranaldi R, Fadda G: Images in endocrine pathology: spindle cell lesion of the thyroid gland. Endocr Pathol 2012, 23(2):132-134.

doi:10.1186/1471-2482-13-S2-S43

Cite this article as: Di Crescenzo et al:: Nodular goiter with amyloid deposition in an elderly patient: fine-needle cytology diagnosis and review of the literature. BMC Surgery 2013 13(Suppl 2):S43.

\section{Submit your next manuscript to BioMed Central and take full advantage of:}

- Convenient online submission

- Thorough peer review

- No space constraints or color figure charges

- Immediate publication on acceptance

- Inclusion in PubMed, CAS, Scopus and Google Scholar

- Research which is freely available for redistribution

Submit your manuscript at www.biomedcentral.com/submit
Biomed Central 